BIOMEDICAL AND BIOSOCIAL ANTHROPOLOGY
Official Journal of the International Academy
of Integrative Anthropology
journal homepage: http://bba-journal.com

\title{
Cerebral small vessel disease and its impact on the course and outcome of stroke
}

Bartiuk R. S.

National Pirogov Memorial Medical University, Vinnytsya, Ukraine

\section{ARTICLE INFO}

Received: 26 June, 2019

Accepted: 29 July, 2019

UDC: $616.831-005.6: 616.831-005.8-$ 031.13: 611.018 .8

\section{CORRESPONDING AUTHOR}

e-mail: rambrs88@gmail.com Bartiuk R. S.
Cerebral small vessel disease (CSVD) is a common cause of stroke (25\% of all strokes) and has a significant contribution to development dementia, functional loss and increases the risk of death. Validation of methods for assessing the total cerebral small vessel disease burden on CT and MRI makes it possible to more accurately and fully assess the impact of the cumulative effect of cerebrovascular pathology on the development and consequences of stroke after 3 months. The aim of our study was to investigate the prognostic value of the total CSVD burden and its individual features (leukoaraiosis, lacunes, brain atrophy) on the course and outcome of stroke at 90 days. 131 patients with ischemic stroke, diagnosed according to TOAST criteria, were enrolled. All patients underwent computed tomography on a General Electric CT/e device (Italy) with a slice thickness of 3-7 $\mathrm{mm}$. Leukoaraiosis was diagnosed and scored by the visual scale of Fazekas and von Swieten. Brain atrophy was assessed separately in central and cortical regions by validated standard template. Lacunes were defined according to the standard protocol. We calculated the total CSVD burden (composed leukoaraiosis, lacunes, brain atrophy) with and without brain atrophy. We assessed the severity of neurological deficit by the NIHSS scale. The functional outcome and the degree of disability or dependence in the daily activities we measured by modified Rankin scale and Barthel index. MMSE was used to assess cognitive function. Statistical analyses were performed by SPSS 25.0 software (IBM Corp., Armonk, NY, USA). We used Student's t-test or Mann-Whitney U test, Pearson or Spearman correlation and regression analysis. Our data have shown that cerebral small vessel disease is negatively correlated with the consequences of stroke and reflect brain frailty and impair regenerative potential. The degree of cognitive deficit was associated with negative prognostic consequences of stroke. The total cerebral small vessel disease burden is a valuable prognostic marker of stroke prognosis and can be used as a tool for the assessment of effectiveness of preventive and curative measures.

Keywords: cerebral small vessel disease, stroke, leukoaraiosis, lacunes, CT.

\section{Introduction}

Cerebral small vessel disease (CSVD) is the cause of $25 \%$ of all ischemic strokes and doubles the risk of their occurrence, is a significant cause of hemorrhagic strokes, cognitive decline, dementia, functional dependence [10]. CSVD is associated with an increased risk of death, disability and is considered a negative prognostic marker of stroke [19]. Acquired and genetic pathologies affecting the small perforated arteries, arterioles and venules of the brain play a role in the etiology of CSVD [3]. The most common sporadic forms of CSVD are hypertensive arteriosclerosis and beta-amyloid angiopathy [12]. The pathogenetic basis of CSVD is not known for sure, but an important role is played by disorders of cerebral autoregulation, inflammation, violation of the integrity of the blood-brain barrier, endothelial dysfunction, impaired beta-amyloid clearance $[20,13,14]$. Neuroimaging is key in the diagnosis of CSVD. Characteristic features of CSVD are leukoaraiosis, lacunae, "fresh" lacunar strokes, cerebral atrophy, microhemorrhages, dilation of perivascular spaces $[4,5]$. A number of previous studies have found the effect of individual CSVD symptoms on the effects of territorial stroke [21,2], but it is more appropriate to assess the cumulative effect of CSVD symptoms on the course and prognosis of stroke, which requires further research. To do this, scales for assessing the overall severity of CSVD have been proposed, which 
have been validated in a number of studies [1, 17]. The overall severity of CSVD may have a negative prognostic effect on quality of life, mortality, and risk of recurrent stroke $[7,9]$.

The aim of the study was to examine the prognostic value of the total severity of CSVD and its individual features (leukoaraiosis, lacunae, cerebral atrophy) on the course and consequences of stroke in the medium term (90 days after stroke).

\section{Materials and methods}

The study was conducted on the basis of a specialized stroke department № 22 Vinnytsya Regional Psychoneurological Hospital named after academician O.I. Yushchenko. All patients underwent spiral computed tomography (SCT) to detect a subtype of stroke. Exclusion criteria were poor quality of SCT scans, a diagnosis of transient ischemic attack or no confirmation of a stroke on SCT or magnetic resonance imaging, no contact with the patient or his relatives 90 days after the disease. Patients were hospitalized no later than 24 hours after stroke.

The diagnosis of ischemic stroke was established by TOAST criteria: atherothrombotic, cardioembolic, lacunar, cryptogenic, other established etiology [6]. Demographics and risk factors were recorded: age, sex, body mass index, place of residence, history of hypertension, diabetes, atrial fibrillation, comorbidities and history of stroke. Clinical and neurological assessment of patients included neurological status studies, the severity of neurological deficits was assessed by the National Institute of Health Stroke Scale (NIHSS) at the time of hospitalization and discharge. The level of disability was assessed on a modified Rankin scale (mRS) $(0=$ independence, 6 = death) at the time of hospitalization, discharge, and 90 days after illness (by telephone interview). The level of daily activity was assessed by the Bartel Index $(\mathrm{BI})$ at the time of discharge and 90 days after the illness (by telephone interview). mRS and BI are key assessment characteristics of stroke outcomes both at the time of illness and in the medium term on day 90 after stroke. Assessment of cognitive functions was performed at the time of discharge on a short scale of assessment of mental status MMSE (Mini-Mental State Examination) [1]. Assessment of the effects of stroke on day 90 was performed as follows: if the NIHSS at admission was 7 points or less and mRS after 3 months is 2-6, the assessment of the effect - "bad"; "good" in this case - 0-1. If NIHSS at admission was 8-14 points, the "bad" result at mRS - 3-6, and "good" - at 0-2. If the NIHSS at admission was 15 points or more, the "bad" result is considered at mRS - 4-6, and "good" - at mRS - 0-3.

SCT scan of the brain was performed on a General Electric CT/e device (Italy) with a tomographic section thickness of 3-7 mm. The volume of the main stroke center was estimated by the formula for determining the volume of the ellipsoid - ABC/2 [18]. Leukoaraiosis was assessed according to Fazekas scale (0-3): 0 - no, 1 - thin periventricular "caps", lines or dots, 2 - moderate drainage leukoaraiosis, 3 - severe drainage leukoaraiosis. And also, according to the von Swieten scale (Fig. 1), according to which the severity of leukoaraiosis was assessed in two regions - around the anterior and posterior horns of the lateral ventricles. Where 0 - the absence of leukoaraiosis, 1 - leukoaraiosis is limited to the area adjacent to the ventricles, not extending to the cortex, 2 leukoaraiosis covers the entire area from the lateral ventricles to the cortex. The assessment is performed at the level of the anterior and posterior horns of the lateral ventricles and can vary from 0 (absence) to 4 (leukoaraiosis extends from the ventricles to the cortex in the anterior and posterior regions of the brain) [11]. Lacunae were defined as round or ovoid foci having signal characteristics identical to cerebrospinal fluid 3 to $20 \mathrm{~mm}$ in diameter, which may be localized in the basal ganglia, inner capsule, crescent center, cortex, brainstem, or cerebellum.

Cerebral atrophy was assessed separately for the cortical and central regions on validated visual scales, according to which the degree of atrophy was defined as absent - 0, moderate - 1 , severe - 2 [16]. The total severity of CSVD was calculated as follows: one point was calculated separately - in the case of severe leukoaraiosis, extending from the anterior or posterior horns of the lateral ventricles to the cortex (Fazekas 3 or von Swieten 2 for anterior or posterior region), in severe cortical or central atrophy (2 degree according to validated scales), in the presence of one or more lacunae. Thus, the maximum severity of CSVD is possible - 3 . The severity of CSVD was also considered without considering atrophy (with a possible value of $0-2$ ), as it is not specific for CSVD, and may occur in other diseases [1].

Statistical analysis of the data was performed in IBM SPSS 25.0 (IBM Corp., Armonk, NY, USA). Student's T-test or Mann-Whitney U-test (for normal data distribution or distribution other than normal, respectively) were used to compare the study groups and characteristics. Pearson or Spearman correlation methods, as well as logistic and linear regression, were used to study correlations.

\section{Results}

Clinical and demographic characteristics of patients are given in table 1. Neuroimaging SCT-characteristics of the subjects are given in table 2. Dynamics of changes in the degree of disability by $\mathrm{mRS}$ at the time of hospitalization, discharge and 90 days after the disease is given in Fig. 2 . The peculiar, different from the population, structure of types of ischemic stroke is due to the specific practice of the department, which is designed for urgent thrombolysis and the selection of patients is performed in favor of mainly territorial strokes of moderate and severe severity.

According to our data, the group of patients who had 


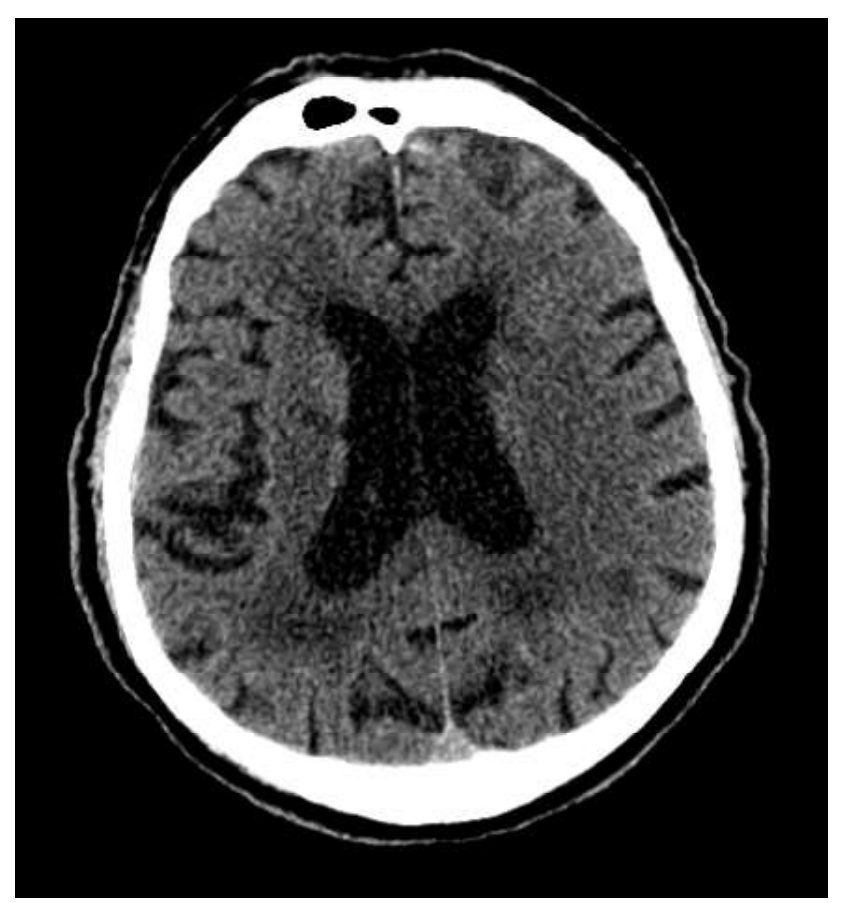

Fig. 1. Degree of leukoaraiosis according to von Swieten scale 4. Leukoaraiosis extends from the ventricles to the cortex in the anterior and posterior regions of the brain.

Table 1. Clinical and demographic characteristics of patients.

\begin{tabular}{|l|c|}
\hline The total number investigated, $\mathrm{n}$ & 131 \\
\hline Age & $64.05 \pm 9.05$ \\
\hline Sex: & \\
male & $88(67.2 \%)$ \\
female & $43(32.6 \%)$ \\
\hline Concomitant diseases: & \\
hypertension & $127(97.1 \%)$ \\
diabetes & $26(20.0 \%)$ \\
varicose & $32(24.4 \%)$ \\
veins chronic & $11(8.4 \%)$ \\
kidney disease & $15(11.6 \%)$ \\
chronic diseases of the gastrointestinal tract & $21(16.1 \%)$ \\
chronic lung disease smoking & $30(23.0 \%)$ \\
\hline History of stroke & $42(32.1 \%)$ \\
\hline Hypertension: & $21(16.0 \%)$ \\
stage 1 & $85(65.0 \%)$ \\
stage 2 & $21(16.1 \%)$ \\
stage 3 & \\
\hline Weight for BMl: & $43(32.8 \%)$ \\
overweight & $41(31.3 \%)$ \\
obesity I degree & $13(10.0 \%)$ \\
obesity II degree & $7(5.3 \%)$ \\
obesity III degree & $73(58.0 \%)$ \\
\hline TOAST-classification of ischemic strokes: & $30(23.0 \%)$ \\
atherosclerotic & $10(7.7 \%)$ \\
cardioembolic & $9(7.0 \%)$ \\
lacunar & $29(22.1 \%)$ \\
cryptogenic & \\
another known reason & \\
\hline NIHSS at hospitalization: & \\
mild degree (1-8 points) & \\
moderate degree (9-12 points) & \\
severe degree (13-15 points) & \\
extremely severe degree (> 15 points) & \\
\hline
\end{tabular}

\section{Continuation of table 1.}

\begin{tabular}{|c|c|}
\hline $\begin{array}{l}\text { NIHSS at discharge: } \\
\text { mild degree (1-8 points) } \\
\text { moderate degree ( } 9-12 \text { points) } \\
\text { severe degree (13-15 points) } \\
\text { extremely severe degree (> } 15 \text { points) }\end{array}$ & $\begin{array}{l}70(53.4 \%) \\
25(19.0 \%) \\
14(10.7 \%) \\
22(16.8 \%)\end{array}$ \\
\hline $\begin{array}{l}\text { Bartel Index (discharge): } \\
\text { severe disability }(0-45 \text { points) } \\
\text { moderate disability }(46-75 \text { points) } \\
\text { minimal disability ( } 76-100 \text { points) }\end{array}$ & $\begin{array}{l}58(44.3 \%) \\
31(24.0 \%) \\
42(32.0 \%)\end{array}$ \\
\hline $\begin{array}{l}\text { Bartel index (90 day): } \\
\text { severe disability ( } 0-45 \text { points) } \\
\text { moderate disability ( } 46-75 \text { points) } \\
\text { minimal disability ( } 76-100 \text { points) }\end{array}$ & $\begin{array}{l}27(21.0 \%) \\
30(23.0 \%) \\
74(56.0 \%)\end{array}$ \\
\hline$($ MMSE < 26) (discharge) & $103(78.6 \%)$ \\
\hline $\begin{array}{l}\text { mRS (at hospitalization): } \\
0 \\
1 \\
2 \\
3 \\
4 \\
5 \\
6\end{array}$ & $\begin{array}{c}0(0 \%) \\
0(0 \%) \\
0(0 \%) \\
14(10.7 \%) \\
70(53.4 \%) \\
47(35.9 \%) \\
0(0 \%)\end{array}$ \\
\hline $\begin{array}{l}\mathrm{mRS} \text { (discharge): } \\
0 \\
1 \\
2 \\
3 \\
4 \\
5 \\
6\end{array}$ & $\begin{array}{c}0(0 \%) \\
19(14.5 \%) \\
20(15.3 \%) \\
29(22.1 \%) \\
49(37.4 \%) \\
7(5.3 \%) \\
7(5.3 \%)\end{array}$ \\
\hline $\begin{array}{l}\text { mRS (90 day): } \\
0 \\
1 \\
2 \\
3 \\
4 \\
5 \\
6\end{array}$ & $\begin{array}{c}15(11.5 \%) \\
23(17.6 \%) \\
33(25.2 \%) \\
30(22.9 \%) \\
13(9.9 \%) \\
1(0.8 \%) \\
16(12.2 \%) \\
\end{array}$ \\
\hline
\end{tabular}

some degree of disease of small vessels of the brain, after three months was characterized by a significantly lower degree of daily activity according to the Barthel index (59 vs. 72, p<0.05). Although at the time of discharge the corresponding difference was 60 against 72, but it was not properly reliable $(p=0.072)$. There was no difference in the size of the main stroke between the respective groups. There was also no difference in the severity of the neurological deficit on the NIHSS scale both at the time of admission and at the time of discharge. Interestingly, the negative effects of stroke on day 90 were observed in the group of patients with severe CSVD $(p<0.05)$. The degree of leukoaraiosis and the presence of lacunae were significantly associated with an increased degree of disability in $\mathrm{mRS}$ and $\mathrm{BI}$ on day $90(r=0.30, p<0.05)$, but no relationship was found for cerebral atrophy. The level of cognitive deficits on the MMSE scale was significantly higher in patients with negative stroke consequences $(p<0.05)$.

\section{Discussion}

Thus, the presence of signs of CSVD negatively affects 
Table 2. SCT characteristics.

\begin{tabular}{|l|c|}
\hline The overall severity of CSVD: & $60(45.8 \%)$ \\
0 & $33(25.2 \%)$ \\
1 & $23(17.6 \%)$ \\
2 & $15(11.5 \%)$ \\
\hline The degree of leukoaraiosis according to von & \\
Swieten scale: & $12(9.2 \%)$ \\
no (0) & $32(24.4 \%)$ \\
mild (1) & $37(28.2 \%)$ \\
moderate (2) & $38(29.0 \%)$ \\
severe (3) & $12(9.2 \%)$ \\
extremely severe (4) & $39(29.8 \%)$ \\
\hline The presence of lacunes: & $92(70.2 \%)$ \\
yes & $16(12.2 \%)$ \\
no & $82(62.6 \%)$ \\
\hline Cortical atrophy: & $33(25.2 \%)$ \\
no (0) & \\
moderate (1) & $91(69.5 \%)$ \\
expressed (2) & $34(26.0 \%)$ \\
\hline Central atrophy: & $6(4.6 \%)$ \\
no (0) & \\
moderate (1) & $57(36.0 \%)$ \\
expressed (2) & $28(21.4 \%)$ \\
\hline The size of the main focus stroke: & \\
small foci (up to 10 ml) & \\
medium foci (11-100 ml) & \\
large foci (more than 100 ml) & \\
\hline & \\
\hline
\end{tabular}

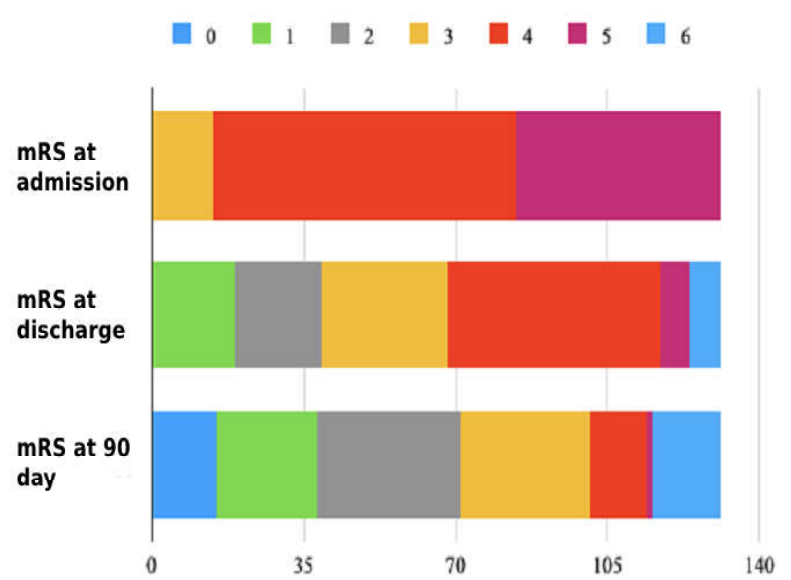

Fig. 2. Dynamics of changes in the degree of disability by $m R S$ at the time of hospitalization, discharge and 90 days after the disease.

\section{References}

[1] Appleton, J. P., Woodhouse, L. J., Adami, A., Becker, J. L., Berge, E., Cala, L. A., ... Wardlaw, J. M. (2020). Imaging markers of small vessel disease and brain frailty, and outcomes in acute stroke. Neurology, 94(5), e439-e452. doi: 10.1212/ WNL.0000000000008881

[2] Arba, F., Palumbo, V., Boulanger, J. M., Pracucci, G., Inzitari, D., Buchan, A. M., ... \& Hill, M. D. (2016). Leukoaraiosis and lacunes are associated with poor clinical outcomes in ischemic stroke patients treated with intravenous thrombolysis. International journal of stroke: official journal of the International. Stroke Society, 11(1), 62-67. doi: 10.1177/1747493015607517

[3] Benjamin, P., Zeestraten, E., Lambert, C., Ster, I. C., Williams, O. A., Lawrence, A. J., ... \& Markus, H. S. (2016). Progression of MRI markers in cerebral small vessel disease: Sample size considerations for clinical trials. Journal of cerebral blood the consequences of stroke in the medium term (three months after a stroke). Our results are similar to a number of other studies [1, 8], but do not affect the degree of neurological deficit at the time of the disease and the size of the main stroke. These results may indicate that the brains of patients with signs of CSVD have a reduced potential for regeneration and recovery. In addition, some features of CSVD (leukoaraiosis, lacunae) also correlate with an increased level of disability, which may have prognostic value and affect rehabilitation potential. Interestingly, neither cortical nor central atrophy correlated with stroke after day 90, but was associated with both leukoaraiosis and lacunae. This observation suggests that atrophy may be secondary to leukoaraiosis and small vessel pathology, as well as other non-vascular causes, and may not accurately reflect the quality of functional connections within the brain. Similar studies on the effect of cerebral atrophy on the effects of stroke have shown that only certain anatomical subtypes of atrophy can have some effect on the effects of stroke [15], so a more detailed analysis is needed. As predicted, the level of cognitive decline negatively affected the effects of stroke after three months, which is consistent with other studies [22].

In the future, it is promising to continue to study the interdependence of CSVD symptoms both among themselves and with other factors, to study the possibility of influencing CSVD, which could improve the rehabilitation potential of stroke patients.

\section{Conclusions}

1. Patients after stroke on day 90 who had signs of CSVD were characterized by a higher degree of disability according to the Barthel index - 59 in contrast to persons without signs of CSVD, in whom the Barthel index was 72. A correlation was found between the severity of CSVD and the level of disability by $\mathrm{mRS}(\mathrm{r}=0.30)$.

2. Diseases of small vessels of the brain and some of its features have prognostic value in relation to the mediumterm consequences of territorial stroke and can be used as a criterion for the effectiveness of preventive, curative and rehabilitation measures.

flow and metabolism: official journal of the International Society of Cerebral Blood Flow and Metabolism, 36(1), 228240. doi: $10.1038 / j \mathrm{cbfm} .2015 .113$

[4] Caruso, P., Signori, R., \& Moretti, R. (2019). Small vessel disease to subcortical dementia: a dynamic model, which interfaces aging, cholinergic dysregulation and the neurovascular unit. Vascular health and risk management, 15, 259-281. doi: 10.2147/NHRM.S190470

[5] Chen, X., Wang, J., Shan, Y., Cai, W., Liu, S., Hu, M., ... \& Lu, Z. (2019). Cerebral small vessel disease: neuroimaging markers and clinical implication. Journal of neurology, 266(10), 23472362. doi: $10.1007 / \mathrm{s} 00415-018-9077-3$

[6] G?k?al, E., Niftaliyev, E., \&Asil, T. (2017). Etiological classification of ischemic stroke in young patients: a comparative study of TOAST, CCS, and ASCO. Acta neurologica Belgica, 117(3), 
643-648. doi: $10.1007 / \mathrm{s} 13760-017-0813-8$

[7] Goldstein, E. D., Badi, M. K., Hasan, T. F., Lesser, E. R., Hodge, D. O., Lin, M. P., \& Meschia, J. F. (2019). Cerebral Small Vessel Disease Burden and All-Cause Mortality: Mayo Clinic Florida Familial Cerebrovascular Diseases Registry. Journal of stroke and cerebrovascular diseases: the official journal of National Stroke Association, 28(12), 104285. doi: 10.1016/ j.jstrokecerebrovasdis.2019.07.001

[8] Huo, Y. C., Li, Q., Zhang, W. Y., Zou, N., Li, R., Huang, S. Y., ... \& Qin, X. Y. (2019). Total Small Vessel Disease Burden Predicts Functional Outcome in Patients With Acute Ischemic Stroke. Frontiers in neurology, 10, 808. doi: 10.3389/fneur.2019.00808

[9] Lau, K. K., Li, L., Schulz, U., Simoni, M., Chan, K. H., Ho, S. L., ... \& Rothwell, P. M. (2017). Total small vessel disease score and risk of recurrent stroke: Validation in 2 large cohorts. Neurology, 88(24), 2260-2267. doi: 10.1212/WNL.0000000000004042

[10] Li, Q., Yang, Y., Reis, C., Tao, T., Li, W., Li, X., \& Zhang, J. H. (2018). Cerebral Small Vessel Disease. Cell transplantation, 27(12), 1711-1722. doi: 10.1177/0963689718795148

[11] Marek, M., Horyniecki, M., Fraczek, M., \& Kluczewska, E. (2018). Leukoaraiosis - new concepts and modern imaging. Polish journal of radiology, 83, e76-e81. doi: 10.5114/pjr.2018.74344

[12] Mustapha, M., Nassir, C., Aminuddin, N., Safri, A. A., \& Ghazali, M. M. (2019). Cerebral Small Vessel Disease (CSVD) - Lessons From the Animal Models. Frontiers in physiology, 10, 1317. doi: 10.3389/fphys.2019.01317

[13] Poggesi, A., Pasi, M., Pescini, F., Pantoni, L., \& Inzitari, D. (2016). Circulating biologic markers of endothelial dysfunction in cerebral small vessel disease: A review. Journal of cerebral blood flow and metabolism: official journal of the International Society of Cerebral Blood Flow and Metabolism, 36(1), 72 94. doi: $10.1038 / \mathrm{jcbfm} .2015 .116$

[14] Qi, X. M., \& Ma, J. F. (2017). The role of amyloid beta clearance in cerebral amyloid angiopathy: more potential therapeutic targets. Translational neurodegeneration, 6, 22. doi: 10.1186/ s40035-017-0091-7

[15] Qu, J. F., Chen, Y. K., Zhong, H. H., Li, W., \& Lu, Z. H. (2019). Preexisting Cerebral Abnormalities and Functional Outcomes
After Acute Ischemic Stroke. Journal of geriatric psychiatry and neurology, 32(6), 327-335. doi: 10.1177/ 0891988719862631

[16] Sato, S., Delcourt, C., Heeley, E., Arima, H., Zhang, S., Al-Shahi Salman, R., ... \&Anderson, C. S. (2016). Significance of Cerebral Small-Vessel Disease in Acute Intracerebral Hemorrhage. Stroke, 47(3), 701-707. doi: 10.1161/STROKEAHA.115.012147

[17] Shu, L., Liang, J., Xun, W., Yang, H., \& Lu, T. (2020). Prediction for the Total MRI Burden of Cerebral Small Vessel Disease With Retinal Microvascular Abnormalities in Ischemic Stroke/ TIA Patients. Frontiers in neurology, 11, 268. doi: 10.3389/ fneur.2020.00268

[18] Sims, J. R., Gharai, L. R., Schaefer, P. W., Vangel, M., Rosenthal, E. S., Lev, M. H., \& Schwamm, L. H. (2009). ABC/2 for rapid clinical estimate of infarct, perfusion, and mismatch volumes. Neurology, 72(24), 2104-2110. doi: 10.1212/ WNL.0b013e3181aa5329

[19] Song, T. J., Kim, J., Song, D., Yoo, J., Lee, H. S., Kim, Y. J., ... \& Kim, Y. D. (2017). Total Cerebral Small-Vessel Disease Score is Associated with Mortality during Follow-Up after Acute Ischemic Stroke. Journal of clinical neurology (Seoul, Korea), 13(2), 187-195. doi: 10.3988/jcn.2017.13.2.187

[20] Wardlaw, J. M., Makin, S. J., Valdes Hernandez, M. C., Armitage, P. A., Heye, A. K., Chappell, F. M., ... \& Thrippleton, M. J. (2017). Blood-brain barrier failure as a core mechanism in cerebral small vessel disease and dementia: evidence from a cohort study. Alzheimer's \& Dementia, 13(6), 634-643. doi: 10.1016/j.jalz.2016.09.006

[21] Zerna, C., Yu, A., Hong, Z., Penn, A., Lesperance, M., Croteau, N., ... \& Coutts, S. (2019). White Matter Hyperintensity Volume Influences Symptoms in Patients Presenting With Minor Neurological Deficits, Stroke, 51(2), 409-415. doi: 10.1161/ STROKEAHA.117.017429

[22] Zinn, S., Dudley, T. K., Bosworth, H. B., Hoenig, H. M., Duncan, P. W., \& Horner, R. D. (2004). The effect of poststroke cognitive impairment on rehabilitation process and functional outcome. Archives of physical medicine and rehabilitation, 85(7), 10841090. doi: 10.1016/j.apmr.2003.10.022

\section{ЗАХВОРЮВАННЯ МІЛКИХ СУДИН МОЗКУ ТА ЙОГО ВПЛИВ НА ПЕРЕБІГ ТА НАСЛІДКИ МОЗКОВОГО ІНСУЛЬТУ \\ Бартюк P. C.}

Захворювання мілких судин мозку (ЗМСМ) є причиною 25 \% усіх інсультів та має вагомий внесок у розвиток деменції, функціональних обмежень та підвищує ризик смерті. Валідація методів оцінки загальної тяжкості захворювання мілких судин мозку на СКТ та МРТ дає можливість більш точно та повноцінно оцінити вплив кумулятивного ефекту патологї мілких судин мозку на розвиток та наслідки мозкового інсульту у середньостроковій перспективі (90-й день). Метою дослідження було вивчення прогностичної цінності загальної тяжкості змСМ та окремих його ознак (лейкоареоз, лакуни, мозкова атрофія) на перебіг та наслідки інсульту у середньостроковій перспективі (через 90 днів після розвитку інсульту). Обстежено та проліковано 131 хворого на ішемічний інсульт, діагноз якого встановлювали за критеріями ТОАST. Усім хворим виконували спіральну комп'ютерну томографію на апараті General Electric CT/е (Iталія) з товщиною томографічного зрізу 3-7 мм. Лейкоареоз оцінювали за шкалою Fazekas та за шкалою von Swieten. Мозкову атрофію оцінювали окремо для кортикального та центрального регіонів за валідованими візуальними шкалами. Розраховували загальну тяжкість змСм $і$ його ступінь тяжкості як з, так і без урахування атрофії. Оцінювали динаміку змін тяжкості неврологічного дефріциту за шкалою національного інституту здоров'я США (NIHSS), рівня інвалідизації - за модифікованою шкалою Ренкіна (тRS), рівня повсякденної активності - за індексом Бартеля (BI). Оцінку когнітивних функцій проводили за короткою шкалою оцінки психічного сmamyсу MMSE. Cmamuстичний аналіз даних проводили у програмі IBM SPSS 25.0 (IBM Corp., Armonk, NY, USA). Використовували Т-критерій Стьюдента або U-критерій Манна-Уітні, методи кореляції Пірсона або Спірмена, а також регресійний аналіз. Наші дані показали, що захворювання мілких судин мозку негативно корелює із наслідками інсульту та свідчить про вразливість мозку та зниження відновного потенціалу. Рівень когнітивного дефіциту асоціювався з негативними прогностичними наслідками інсульту. Загальна тяжкість захворювання мілких судин мозкує цінним прогностичним маркером наслідків мозкового інсульту та може використовуватись в якості критерія ефективності превентивних та лікувальних заходів.

Ключові слова: захворювання мілких судин мозку, інсульт, лейкоареоз, лакуни, СКТ. 


\section{ЗАБОЛЕВАНИЕ МЕЛКИХ СОСУДОВ МОЗГА И ЕГО ВЛИЯНИЕ НА ТЕЧЕНИЕ И ПОСЛЕДСТВИЯ МОЗГОВОГО ИНСУЛЬТА Бартюк Р. C.}

Заболевания мелких сосудов мозга (ЗМСМ) является причиной 25 \% всех инсультов и имеет весомый вклад в развитие деменции, функциональных ограничений и повышает риск смерти. Валидация методов оценки общей тяжести заболевания мелких сосудов мозга на СКТ и МРТ дает возможность более точно и полноценно оценить влияние кумулятивного эфрфекта патологии мелких сосудов мозга на развитие и последствия мозгового инсульта в среднесрочной перспективе (90-й день). Целью исследования было изучение прогностической ценности общей тяжести змСМ и отдельных его признаков (лейкоареоз, лакуны, мозговая атрофия) на течение и последствия инсульта в среднесрочной перспективе (через 90 дней после развития инсульта). Обследовано и пролечено 131 больного с ишемическим инсультом, диагноз которого устанавливали по критериям TOAST. Всем больным выполняли спиральную компьютерную томографию на аппарате General Electric CT/e (Италия) с толщиной томографического среза 3-7 мм. Лейкоареоз оценивали по шкале Fаzеkаs и по шкале von Swieten. Мозговую атрофию оценивали отдельно для кортикального и центрального регионов по валидированным визуальным шкалам. Рассчитывали общую тяжесть змСМ и его степень тяжести, как с учетом, так и без учета атрофии. Оценивали динамику изменений тяжести неврологического дефицита по шкале Национального института здоровья США (NIHSS), уровня инвалидизации - по модифицированной шкале Рэнкина (mRS), уровня повседневной активности - по индексу Бартеля (BI). Оценку когнитивных функций проводили по короткой шкале оценки психического статуса ММSE. Cтатистический анализ данных проводили в программе IBM SPSS 25.0 (IBM Corp., Armonk, NY, USA). Использовали Tкритерий Стьюдента или U-критерий Манна-Уитни, методы корреляции Пирсона или Спирмена, а также регрессионный анализ. Наши данные показали, что заболевание мелких сосудов мозга отрицательно коррелирует с последствиями инсульта и свидетельствует об уязвимости мозга и снижения восстановительного потенциала. Уровень когнитивного дефицита ассоциировался с отрицательными прогностическими последствиями инсульта. Общая тяжесть заболевания мелких сосудов мозга является ценным прогностическим маркером последствий мозгового инсульта и может использоваться в качестве критерия эфрфективности превентивных и лечебных мероприятий.

Ключевые слова: заболевание мелких сосудов мозга, инсульт, лейкоареоз, лакуны, СКТ. 